\title{
Correction: Cellular and molecular basis for stress-induced depression
}

\author{
J.-S. Seo ${ }^{1} \cdot$ J. Wei ${ }^{2} \cdot$ L. Qin ${ }^{2} \cdot$ Y. Kim ${ }^{1} \cdot$ Z. Yan ${ }^{2} \cdot$ P. Greengard ${ }^{1}$
}

Published online: 22 October 2019

(c) The Author(s) 2019. This article is published with open access

Correction: Molecular Psychiatry (2017) 22:1440-1447

https://doi.org/10.1038/mp.2016.118

published online 26 July 2016

Following publication of this article, the authors noticed that an incorrect blot image was provided for $\beta$-actin in Supplementary Fig. 2, due to a data processing error. The corrected version of Supplementary Fig. 2 is displayed below. The authors would like to apologise for this error and any inconvenience it may have caused. This has not been corrected in the PDF or HTML versions of the article.
Open Access This article is licensed under a Creative Commons Attribution-NonCommercial-NoDerivatives 4.0 International License, which permits any non-commercial use, sharing, distribution and reproduction in any medium or format, as long as you give appropriate credit to the original author(s) and the source, and provide a link to the Creative Commons license. You do not have permission under this license to share adapted material derived from this article or parts of it. The images or other third party material in this article are included in the article's Creative Commons license, unless indicated otherwise in a credit line to the material. If material is not included in the article's Creative Commons license and your intended use is not permitted by statutory regulation or exceeds the permitted use, you will need to obtain permission directly from the copyright holder. To view a copy of this license, visit http://creativecommons.org/licenses/by-nc-nd/4.0/.

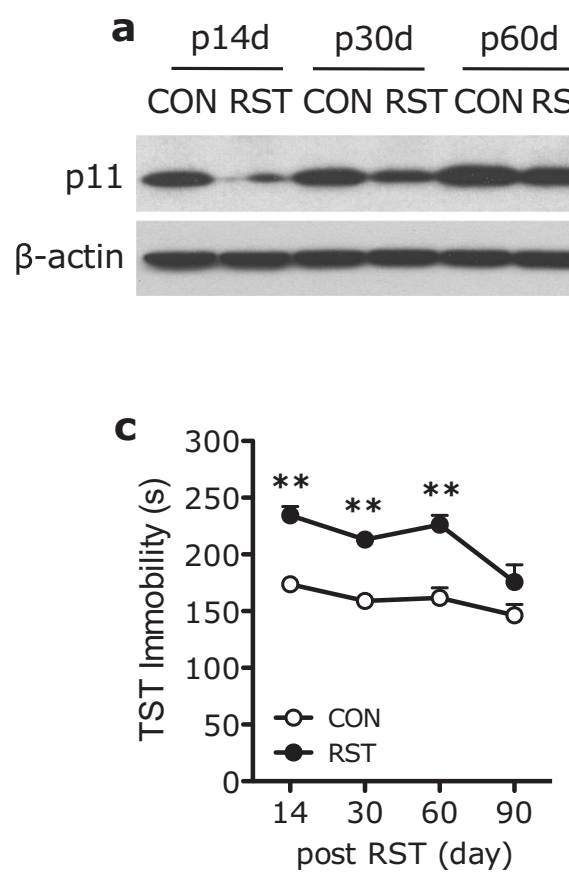

P. Greengard

greengard@ rockefeller.edu

1 Laboratory of Molecular and Cellular Neuroscience, The Rockefeller University, New York, NY, USA b
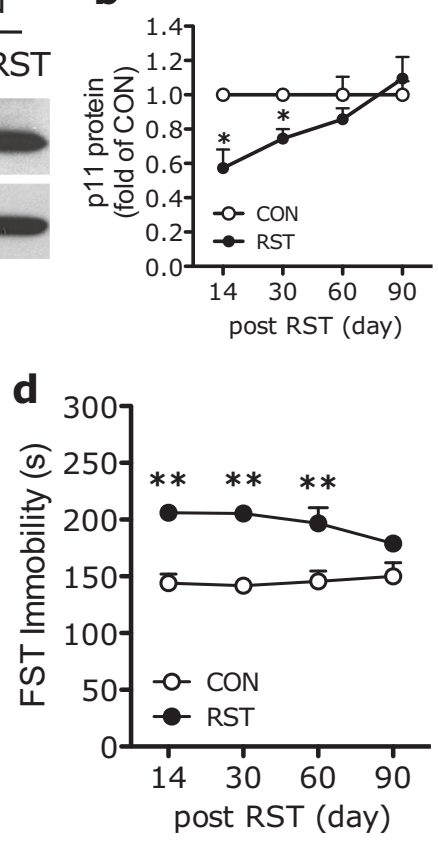

2 Department of Physiology and Biophysics, School of Medicine and Biomedical Sciences, State University of New York, Buffalo, NY, USA 